\title{
Isolation and characterization of virulent Aeromonas veronii from ascitic fluid of oscar Astronotus ocellatus showing signs of infectious dropsy
}

\author{
K. Sreedharan ${ }^{1}$, R. Philip ${ }^{2}$, I. S. Bright Singh ${ }^{1, *}$ \\ ${ }^{1}$ National Centre for Aquatic Animal Health, and ${ }^{2}$ Department of Marine Biology, Microbiology and Biochemistry, \\ School of Marine Sciences, Cochin University of Science and Technology, Fine Arts Avenue, Cochin 682 016, Kerala, India
}

\begin{abstract}
The cichlid oscar Astronotus ocellatus has worldwide commercial value in the pet fish industry because of its early maturation, relatively high fecundity, ability to identify its caretaker and also to alter colouration amongst conspecifics. Pathogenic strains of Aeromonas veronii resistant to multiple antibiotics were isolated from A. ocellatus individuals showing signs of infectious abdominal dropsy. The moribund fish showed haemorrhage in all internal organs, and pure cultures could be obtained from the abdominal fluid. The isolates recovered were biochemically identified as $A$. veronii biovar sobria and genetically confirmed as $A$. veronii based on 16S rRNA gene sequence analysis (GenBank accession no. FJ573179). The RAPD profile using 3 primers (OPA-3, OPA-4 and OPD-20) generated similar banding patterns for all isolates. They displayed cytotoxic and haemolytic activity and produced several exoenzymes which were responsible for the pathogenic potential of the isolates. In the representative isolate MCCB 137, virulence genes such as enterotoxin act, haemolytic toxin aerA, type 3 secretion genes such as aexT, ascV and ascF-ascG, and gcat (glycerophospholipidcholesterol acyltransferase) could be amplified. MCCB 137 exhibited a $50 \%$ lethal dose (LD 50 of $10^{5.071}$ colony-forming units $\mathrm{ml}^{-1}$ in goldfish and could be subsequently recovered from lesions as well as from the internal organs. This is the first description of a virulent $A$. veronii from oscar.
\end{abstract}

KEY WORDS: Aeromonas veronii · Oscar · Astronotus ocellatus · Virulence $\cdot$ Ornamental fishes Resale or republication not permitted without written consent of the publisher

\section{INTRODUCTION}

Aeromonas spp. are primary pathogens of freshwater fish or secondary opportunistic pathogens of compromised or stressed hosts (Jeney \& Jeney 1995). Of the Aeromonas spp., A. hydrophila, A. bestiarum, A. salmonicida, A. veronii biovar sobria, A. caviae, $A$. veronii and $A$. jandaei have been reported as pathogens of various fish species (Kozinska et al. 2002, Rahman et al. 2002, Shome et al. 2005, Wahli et al. 2005, Hossain 2008, Martínez-Murcia et al. 2008, Sreedharan 2008). Motile aeromonads are associated with more than one disease, manifested through several clinical signs such as fin rot/tail rot, ulceration, exophthalmia and abdominal distention (dropsy).
They are responsible for motile aeromonad septicaemia (MAS) and bacterial haemorrhagic septicaemia (BHS) and are associated with epizootic ulcerative syndrome in numerous freshwater (Rahman et al. 2004, Shao et al. 2004) and marine species (Lilley et al. 1997).

Among the aeromonads, Aeromonas veronii has the greatest range in virulence (Janda \& Kokka 1991). A. veronii was originally described by HickmanBrenner et al. (1987) as a novel species in the genus Aeromonas that had previously been referred to by the Center for Disease Control as Enteric Group 77. Genetic studies have indicated that this species consists of 2 biovars, $A$. veronii biovar sobria, which is negative for esculin hydrolysis and ornithine decarboxy- 
lase, and $A$. veronii biovar veronii, which is positive for these reactions (Altwegg et al. 1990, Carnahan \& Altwegg 1996). The incidence of $A$. veronii from diseased fishes has been reported (Hossain 2008, Ma et al. 2009), but not from oscar Astronotus ocellatus.

The oscar is a cichlid that has worldwide commercial value as an ornamental fish (Staeck \& Linke 1995) because of its early maturation and relatively high fecundity (Paiva \& Nepomuceno 1989). These fish are regarded as being among the most intelligent tropical fish species, as they identify their caretakers and sense their surroundings (Von 2010). The species is able to rapidly alter its colouration, a trait which facilitates ritualized territorial and combat behaviours amongst conspecifics (Beeching 1995).

While carrying out a survey on diseases of ornamental fishes across the state of Kerala, India, characteristic abdominal dropsy was detected among oscar, from which Aeromonas in pure culture was isolated especially from the ascitic fluid. This paper describes characterization of the isolates and their pathogenicity, giving insight into their role in the development of dropsy in fishes.

\section{MATERIALS AND METHODS}

Diseased fish. A few (4) moribund fishes from among a population of oscar were bought from an ornamental fish breeding unit. They showed anorexia and lethargy, and exhibited clinical signs of dropsy such as distended abdomen, scale protrusion and petechial haemorrhage. On postmortem examination, the ascitic fluid appeared straw yellow. A water sample was collected from the rearing facility and major parameters ( $\mathrm{pH}$, dissolved oxygen, ammonia, alkalinity and hardness) were measured (APHA 1995).

Isolation of the associated bacteria. The abdominal fluid was serially diluted in physiological saline and spread-plated onto nutrient agar (peptone, $5.0 \mathrm{~g} \mathrm{l}^{-1}$; beef extract, $5.0 \mathrm{~g} \mathrm{l}^{-1}$; $\mathrm{NaCl}, 5.0 \mathrm{~g} \mathrm{l}^{-1}$; agar, $20.0 \mathrm{~g} \mathrm{l}^{-1}$; $\mathrm{pH} 7.5 \pm 0.3$ ). The plates were incubated at $28^{\circ} \mathrm{C}$ for 24 to $48 \mathrm{~h}$. Colonies were isolated at random from all plates to nutrient agar slants and their purity was confirmed by repeated streaking on plates of the same medium and by subsequent Gram staining and observation.

Phenotypic characterization. The isolates were examined for Kovac's cytochrome oxidase, O/129 sensitivity (Oxoid), catalase, production of hydrogen sulphide in triple sugar iron (TSI), arginine dihydrolase, lysine and ornithine decarboxylase, indole production, methyl red test, Voges-Proskauer reaction (acetoin production), citrate utilization, urease production, phenylalanine deaminase, gluconate oxidation, ni- trate reduction, ortho-nitrophenyl-galactoside oxidation ( $\beta$-galactosidase production), and acid production from sugars as described by Collee et al. (1996). The isolates were tested for hydrolysis of esculin (Wilcox et al. 1992), production of alkylsulphatase (Janda et al. 1996), pyrazinamidase (Carnahan et al. 1990), and utilization of DL-lactate (Janda et al. 1996), malonate and acetate (Ewing 1986). The identification was accomplished following Aerokey II (Carnahan et al. 1991).

Random amplified polymorphic DNA (RAPD). RAPD-PCR was carried out using a set of 3 primers (OPA-3: AGT CAG CCA C; OPA-4: AAT CGG GCT C; and OPD-20: ACC CGG TCA C) as previously described (Sudheesh et al. 2002). The reaction mixture consisted of $2.5 \mu \mathrm{l}$ of $10 \times$ buffer, $1.5 \mu \mathrm{l}$ of $25 \mathrm{mM} \mathrm{MgCl}_{2}$, $1.5 \mu \mathrm{l}$ of $10 \mathrm{pmol}$ of oligonucleotide primer, $1.0 \mu \mathrm{l}$ of DNA template, $2 \mu \mathrm{l}$ of $2.5 \mathrm{mM}$ of each deoxynucleoside triphosphate and $1.0 \mu \mathrm{l}$ of Taq polymerase in a total volume of $25 \mu \mathrm{l}$. The reaction was performed in a DNA thermal cycler (Eppendorf), and the amplification conditions consisted of initial denaturation at $95^{\circ} \mathrm{C}$ for $4 \mathrm{~min}$, followed by 45 cycles of denaturation at $94^{\circ} \mathrm{C}$ for $1 \mathrm{~min}$, annealing at $36^{\circ} \mathrm{C}$ for $1 \mathrm{~min}$ and primer extension at $72^{\circ} \mathrm{C}$ for $2 \mathrm{~min}$, with a final extension at $72^{\circ} \mathrm{C}$ for $10 \mathrm{~min}$. The amplified products were electrophoresed on $1.2 \%$ agarose gels in Tris-acetate-EDTA (TAE) buffer at a constant current of $60 \mathrm{~mA}$.

Molecular identification by $16 \mathrm{~S}$ rRNA gene sequence analysis. As all isolates were phenotypically identical, one representative culture (MCCB 137) was chosen for 16S rRNA gene sequence analysis.

Extraction of total DNA: Cell suspension (1 ml) grown in Luria Bertani (LB) medium was centrifuged at $10000 \times g\left(10 \mathrm{~min}, 4^{\circ} \mathrm{C}\right)$, and the pellet was resuspended in $500 \mu \mathrm{l}$ TE buffer $(10 \mathrm{mM}$ Tris/HCl, $1 \mathrm{mM}$ EDTA, pH 8.0) and centrifuged at $10000 \times g(10 \mathrm{~min}$, $4^{\circ} \mathrm{C}$ ). The pellet was resuspended in $500 \mu \mathrm{l}$ lysis buffer (Tris-HCl 0.05 mM, pH 8.0, EDTA $0.05 \mathrm{mM}, \mathrm{NaCl}$, $0.1 \mathrm{mM}$, SDS 2\%, PVP $0.2 \%$ and $0.1 \%$ mercaptoethanol; Lee et al. 2003) and $10 \mu \mathrm{l}$ of Proteinase K were added and incubated initially for $1 \mathrm{~h}$ at $37^{\circ} \mathrm{C}$ and then for $2 \mathrm{~h}$ at $55^{\circ} \mathrm{C}$. Further extraction was carried out by phenol-chloroform extraction method as described by Sambrook \& Russell (2001).

Amplification of the 16S rRNA gene from extracted DNA: 16S rRNA gene amplification was accomplished following Reddy et al. (2000) and employing the universal primers 16S1 (GAG TTT GAT CCT GGC TCA) and 16S2 (ACG GCT ACC TTG TTA CGA CTT).

The reaction was performed in a DNA thermal cycler (Eppendorf) with reaction mixtures (final volume $25 \mu \mathrm{l}$ ) containing $2.5 \mu \mathrm{l}$ of $10 \times$ buffer, $1.5 \mu \mathrm{l}$ of $25 \mathrm{mM} \mathrm{MgCl}_{2}$, $1.0 \mu \mathrm{l}$ of $10 \mathrm{pmol}$ of each oligonucleotide primer, $1.0 \mu \mathrm{l}$ of DNA template, $2 \mu \mathrm{l}$ of $2.5 \mathrm{mM}$ of each deoxynucleoside triphosphate and $1 \mu \mathrm{l}$ of Taq DNA polymerase. 
The amplification profile consisted of initial denaturation at $95^{\circ} \mathrm{C}$ for $5 \mathrm{~min}$, followed by 34 cycles of denaturation at $94^{\circ} \mathrm{C}$ for $20 \mathrm{~s}$, annealing at $58^{\circ} \mathrm{C}$ for $30 \mathrm{~s}$ and extension at $68^{\circ} \mathrm{C}$ for $2 \mathrm{~min}$, with a final extension of $68^{\circ} \mathrm{C}$ for $10 \mathrm{~min}$.

The PCR products were analyzed by electrophoresis on a $1 \%$ agarose gel prepared in $1 \times$ TAE buffer. The gels were stained with ethidium bromide $\left(0.5 \mu \mathrm{g} \mathrm{ml}^{-1}\right)$, visualised on a UV light transilluminator and documented.

Cloning onto pGEM-T Easy vector: The PCR product was cloned into pGEM-T Easy vector (Promega) as per the manufacturer's instructions and used for transforming Escherichia coli JM 109. Plasmids from the positive clones were extracted using the GenElute HP plasmid miniprep kit (Sigma-Aldrich). Nucleotide sequencing was performed using an ABI PRISM 3700 Big Dye Sequencer at Microsynth AG, Switzerland. The primers used were T7 (TAA TAC GAC TCA CTA TAG GG) and SP6 (GAT TTA GGT GAC ACT ATA G).

16S rRNA gene sequence similarity and phylogenetic analysis: Sequenced DNA data were compiled and analysed, and matched with the GenBank database using the Basic Local Alignment Search Tool (BLAST) algorithm (Altschul et al. 1990) from the NCBI website (www.ncbi.nlm.nih.gov). The sequences were multiply aligned using the programme Clustal W (Thompson et al. 1994). Genetic distances were obtained using Kimura's 2-parameter model (Kimura 1980), and a phylogenetic tree was constructed by the neighbour-joining method (Saitou \& Nei 1987) using the software MEGA4 (Tamura et al. 2007).

Phenotypic expression of virulence: in vitro assays. All isolates were tested for the production of DNase (Jeffries et al. 1957), caseinase, chitinase, phospholipase (lecithinase), gelatinase and degradation of tributyrin (for lipase; Collee et al. 1996). Elastase activity on solid medium was detected by spot inoculating the organisms on LB medium supplemented with $0.2 \%$ elastin-Congo red (Sigma-Aldrich) with a clear zone around the growth and diffusion of Congo red into the clear zone, and haemolytic activity on LB agar containing $5 \%$ (vol/vol) human blood (Swift et al. 1999). The other virulence traits tested were slime formation (Freeman et al. 1989) and surface hydrophobicity (Rosenberg et al. 1980, Scoaris et al. 2008). Cytotoxicity of culture supernatant was examined on Hep-2 cells by incubating exponentially growing cells with the supernatant following the 3-(4,5-dimethylthiazol-2-yl)2,5diphenyltetrazolium bromide (MTT) assay (Mosmann 1983, Greenman et al. 1997).

Detection of virulence genes. The representative culture, MCCB 137, was subjected to PCR to detect virulence genes such as enterotoxins (act, alt and ast), haemolytic toxins (hlyA and aerA), genes involved in the type 3 secretion system (TTSS: asc $V$, aexT, aopP, aopO, ascF-asc $G$ and aopH), and glycerophospholipid-cholesterol acyltransferase (gcat). The previously described primers and PCR conditions were used for the specific amplification of virulence genes. Characteristics of primers used for the PCR amplification of virulence genes are summarized in Table 1 . The PCR products were visualised in a $1.5 \%$ gel stained with ethidium bromide.

Antibiotic susceptibility test. Susceptibility to selected antibiotics was tested on nutrient agar plates by the disc diffusion method of Bauer et al. (1966). Briefly, the nutrient agar plates were swabbed with cultures of the isolates grown overnight. Ready-made antibiotic discs from HiMedia Laboratories were aseptically placed on the swabbed plates. The plates were incubated at $28 \pm$ $1^{\circ} \mathrm{C}$ for $18 \mathrm{~h}$, and the clearing zone formed around the discs was recorded using $\mathrm{Hi}$ Antibiotic Zone Scale (HiMedia). The multiple antibiotic resistance (MAR) index (number of antibiotics to which the isolate was resistant/total number of antibiotics tested) was determined for each isolate (Krumperman 1985).

Pathogenicity in vivo. The pathogenicity of Aeromonas MCCB 137 in vivo was tested on goldfish Carassius carassius as the challenge model. All experiments were conducted in a bioassay system. The fish (weighing about 10 to $15 \mathrm{~g}$ ) were anaesthetised using clove oil $(80 \mathrm{ppm})$. For $50 \%$ lethal dose $\left(\mathrm{LD}_{50}\right)$ determination, 5 groups of 7 fish each were intramuscularly injected with $0.1 \mathrm{ml}$ of a saline suspension of the pathogen at $10^{4}, 10^{5}, 10^{6}, 10^{7}$ and $10^{8}$ colony-forming units (CFU) $\mathrm{ml}^{-1}$. One group that served as a control was injected with $0.1 \mathrm{ml}$ of saline. Morbidity and death of the fishes were monitored daily for $7 \mathrm{~d}$, and the moribund specimens were subjected to routine bacteriological examination for re-isolation of the organism. The $\mathrm{LD}_{50}$ was calculated following Reed \& Muench (1938).

\section{RESULTS}

\section{Phenotypic and molecular characterization}

All cultures $(\mathrm{n}=20)$ were of uniform colony morphology (circular, entire, convex and opaque light brown), Gram-negative short rods, motile, fermentative with gas production from glucose, Kovac's oxidase positive and with uniformity in all other characteristics examined (Table 2). On the basis of phenotypic characteristics, the isolates were identified as Aeromonas veronii biovar sobria.

The PCR product (1506 bp) of the 16S rRNA gene of Aeromonas MCCB 137 (1.5 kb) was subjected to sequencing after purification and cloning. The BLAST 
Table 1. Primers (F: forward; R: reverse) used for the amplification of virulence genes

\begin{tabular}{|c|c|c|c|c|}
\hline Virulence gene & Primer & DNA sequence $\left(5^{\prime}-3^{\prime}\right)$ & Product size (bp) & Source \\
\hline \multicolumn{5}{|l|}{ Enterotoxins } \\
\hline \multirow[t]{2}{*}{ act } & $\mathrm{F}$ & AGAAGGTGACCACCAAGAACA & 232 & Kingombe et al. (1999) \\
\hline & $\mathrm{R}$ & AACTGACATCGGCCTTGAACTC & & \\
\hline \multirow[t]{2}{*}{ ast } & $\mathrm{F}$ & TCTCCATGCTTCССТТССАСТ & 331 & Kingombe et al. (1999) \\
\hline & $\mathrm{R}$ & GTGTAGGGATTGAAGAAGCCG & & \\
\hline \multirow[t]{2}{*}{ alt } & F & TGACCCAGTCCTGGCACGGC & 442 & Kingombe et al. (1999) \\
\hline & $\mathrm{R}$ & GGTGATCGATCACCACCAGC & & \\
\hline \multicolumn{5}{|c|}{ Haemolytic toxins } \\
\hline aerA & $\begin{array}{l}\mathrm{F} \\
\mathrm{R}\end{array}$ & $\begin{array}{l}\text { CCCGCCGATCTGCAACCGGG } \\
\text { CTGGTCTGGATAGACGGGCTCTGCC }\end{array}$ & 489 & Ormen \& Ostensvik (2001) \\
\hline \multirow[t]{2}{*}{ hlyA } & F & GGCCGGTGGCCCGAAGATACGGG & 597 & Heuzenroeder et al. (1999) \\
\hline & $\mathrm{R}$ & GGCGGCGCCGGACGAGACGGG & & \\
\hline \multicolumn{5}{|c|}{ Type 3 secretion genes } \\
\hline aexT & $\begin{array}{l}\mathrm{F} \\
\mathrm{R}\end{array}$ & $\begin{array}{l}\text { GGCGCTTGGGCTCTACAC } \\
\text { GAGCCCGCGCATCTTCAG }\end{array}$ & 535 & Burr \& Frey (2007) \\
\hline $\operatorname{asc} V$ & $\begin{array}{l}\mathrm{F} \\
\mathrm{R}\end{array}$ & $\begin{array}{l}\text { GCCCGTTTTGCCTATCAA } \\
\text { GCGCCGATATCGGTACCC }\end{array}$ & 807 & Burr \& Frey (2007) \\
\hline аорP & $\begin{array}{l}\mathrm{F} \\
\mathrm{R}\end{array}$ & $\begin{array}{l}\text { GAGAGTTGGCTAGCGGTGAG } \\
\text { TCCTCATGGAGCGCATCCAG }\end{array}$ & 490 & Burr \& Frey (2007) \\
\hline аорО & $\begin{array}{l}F \\
R\end{array}$ & $\begin{array}{l}\text { CGAGACAGACAAGTTTGC } \\
\text { TGTCGTTGTGGACTATCC }\end{array}$ & 401 & Burr \& Frey (2007) \\
\hline аорH & $\begin{array}{l}\mathrm{F} \\
\mathrm{R}\end{array}$ & $\begin{array}{l}\text { TCAATCAGGACGATGTCG } \\
\text { GTTGGCATTGAGATCTGC }\end{array}$ & 518 & Burr \& Frey (2007) \\
\hline$a s c F-a s c G$ & $\begin{array}{l}\mathrm{F} \\
\mathrm{R}\end{array}$ & $\begin{array}{l}\text { ATGAGGTCATCTGCTCGCGC } \\
\text { GGAGCACAACCATGGCTGAT }\end{array}$ & 789 & Wu et al. (2007) \\
\hline GCAT & $\begin{array}{l}\mathrm{F} \\
\mathrm{R}\end{array}$ & $\begin{array}{l}\text { CTCCTGGAATCCCAAGTATCAG } \\
\text { GGCAGGTTGAACAGCAGTATCT }\end{array}$ & 237 & Nerland (1996) \\
\hline
\end{tabular}

results of the sequence obtained matched $99.7 \%$ with A.veronii. A phylogenetic tree could be constructed with its most similar matches in the GenBank database (Fig. 1), and the sequence was submitted under accession no. FJ573179.

\section{RAPD profile}

The RAPD patterns of all isolates were identical and were therefore considered genetically related. The fingerprints of the isolates consisted of 6 to 12 bands ranging from 250 to 2450 bp (Fig. 2). The maximum number of bands was exhibited by the primer OPD-20 (12 bands at positions 1650, 1550, 1150, 1050, 900, 750, $650,600,550,450,400$ and 300), followed by OPA-3 (8 bands at positions 2450, 1150, 900, 850, 750, 700, 600 and 250) and OPA-4 (6 bands at positions 1850, 1650, $1500,850,600$ and 450).

\section{Phenotypic expression of virulence and detection of virulence genes}

All isolates produced amylase, lipase, lecithinase, DNase, caseinase, chitinase and gelatinase, but not elastase. All were haemolytic on human blood agar and produced slime. They were hydrophobic and cytotoxic to the Hep-2 cell line. Major cytopathic effects included rounding, granulation and cell burst (Fig. 3). In the representative strain, Aeromonas MCCB 137, the virulence genes such as enterotoxin act and haemolytic toxin aer $A$, and type 3 secretion genes such as aexT, asc $V$ and ascF-ascG, and gcat could be amplified (Fig. 4).

\section{Antibiotic susceptibility and expression of pathogenicity in vivo}

All 20 strains isolated in this study exhibited the same antibiotic susceptibility pattern (Table 3 ) and had a MAR index of 0.3 .

Virulence of the representative strain Aeromonas MCCB 137 was assessed in vivo based on the $\mathrm{LD}_{50}$ values in goldfish as the test model, and it was found to be $10^{5.071} \mathrm{CFU} \mathrm{ml}{ }^{-1}$. External signs such as reddening at the site of injection appeared in both experimental and control groups as early as $1 \mathrm{~h}$ post infection. However, further signs of haemorrhagic scale pockets and loss of scales at the site of injection were only observed in test fish. 
Table 2. Phenotypic characterization of the bacterial isolates from oscar $(\mathrm{n}=20)$. MOF: marine oxidation fermentation; F: fermentative; TSI: triple sugar iron; ONPG: orthonitrophenyl- $\beta$-galactoside

\begin{tabular}{|c|c|}
\hline Phenotypic characteristic & Result \\
\hline Gram stain & - \\
\hline Motility & + \\
\hline MOF & $\mathrm{F}$ \\
\hline Kovac's oxidase & + \\
\hline Catalase & + \\
\hline O/129 sensitivity & - \\
\hline Nitrate reduction & + \\
\hline Indole production & + \\
\hline Voges-Proskauer reaction & - \\
\hline Methyl red test & + \\
\hline \multicolumn{2}{|l|}{ Utilization of: } \\
\hline citrate & - \\
\hline malonate & - \\
\hline acetate & - \\
\hline DL-lactate & - \\
\hline Reaction on TSI & Alkaline slant/acid butt \\
\hline Oxidation of ONPG & + \\
\hline Gluconate oxidation & - \\
\hline \multicolumn{2}{|l|}{ Production of: } \\
\hline urease & - \\
\hline alkyl sulphatase & + \\
\hline pyrazinamidase & + \\
\hline Hydrolysis of esculin & - \\
\hline Arginine dihydrolase & + \\
\hline Lysine decarboxylase & + \\
\hline Ornithine decarboxylase & - \\
\hline \multicolumn{2}{|l|}{ Acid production from: } \\
\hline sucrose & + \\
\hline D-fructose & + \\
\hline D-mannose & + \\
\hline D-mannitol & + \\
\hline D-maltose & + \\
\hline trehalose & + \\
\hline dextrin & + \\
\hline starch & + \\
\hline D-galactose & + \\
\hline D-ribose & + \\
\hline glycerol & + \\
\hline salicin & - \\
\hline D-sorbitol & - \\
\hline L-rhamnose & - \\
\hline D-melibiose & - \\
\hline m-inositol & - \\
\hline raffinose & - \\
\hline D-lactose & - \\
\hline adonitol & - \\
\hline D-cellobiose & + \\
\hline inulin & - \\
\hline L-arabinose & - \\
\hline
\end{tabular}

\section{DISCUSSION}

Husbandry of ornamental fish is gaining popularity worldwide, leading to the opening of prospective markets with increased employment opportunities. In accordance with the global scenario, the ornamental fish trade in India has also been showing signs of improvement. Most of the ornamental fishes cultured and marketed in India are exotic species; based on FAO export data, India was ranked 26th in the world in 2004, accounting for $0.5 \%$ of world exports (FAO 2006). In India, several governmental agencies such as the Marine Products Development Authority (MPEDA) and Kerala Aqua Ventures International Ltd (KAVIL) have been involved to boost ornamental fish production. As in any other aquaculture practice, the intensification of ornamental fish culture has led to the emergence of diseases and mortality with varied manifestations. In our study, we found that Aeromonas spp. were the associated bacterial flora in the majority of disease outbreaks.

Aeromonas spp. are the most frequently encountered bacterial agents associated with fish diseases in freshwater tropical environments (Karunasagar et al. 2003). The presence of virulence and antibiotic-resistance genes in Aeromonas isolates from fresh water is probably also responsible for human infections (Henriques et al. 2006, Scoaris et al. 2008). Moreover, there have been reports on zoonoses of infectious Aeromonas from fishes following injuries during handling, working in aquaculture systems, or pet fish keeping (Filler et al. 2000, Lehane \& Rawlin 2000). In view of these reports, a comprehensive study was undertaken to look into the characteristics, virulence potential and antibiotic susceptibility pattern of Aeromonas spp. recovered from diseased ornamental fishes.

Aeromonas spp. is considered to be an opportunistic agent that only provokes clinical signs in stressed fish or fish affected by concurrent infections (van der Marel et al. 2008). The major predisposing stress factors include temperature shock, low oxygen level, high ammonia and other adverse water quality problems (Plumb \& Hanson 2010). In our study, the $\mathrm{pH}$ in the rearing facility was low (5.8), as were dissolved oxygen ( $3 \mathrm{mg} \mathrm{l}^{-1}$ ) and hardness (25 $\mathrm{mg} \mathrm{l}^{-1}$ ). These sub-optimal husbandry conditions in the rearing facility may have made the fish susceptible to the infection, suggesting that in order to avoid an infection from Aeromonas in aquaculture, the fish should be maintained free from stressors.

Information on diseases of oscar is fairly sparse, with the exception of several reports on bacterial infections (McCormick et al. 1995, Soltani et al. 1998, Tukmechi et al. 2009) and parasitic infestations (Kim et al. 2002, Toksen 2006). In the present study, the organisms recovered from oscar could be identified as Aeromonas veronii biovar sobria based on their phenotypic characteristics. However, 16S rRNA gene sequence analysis and multiple alignment with sequences from the GenBank database revealed that the representative isolate Aeromonas MCCB 137 exhibited 99.7\% similarity with $A$. veronii, and only $98.7 \%$ with $A$. veronii 


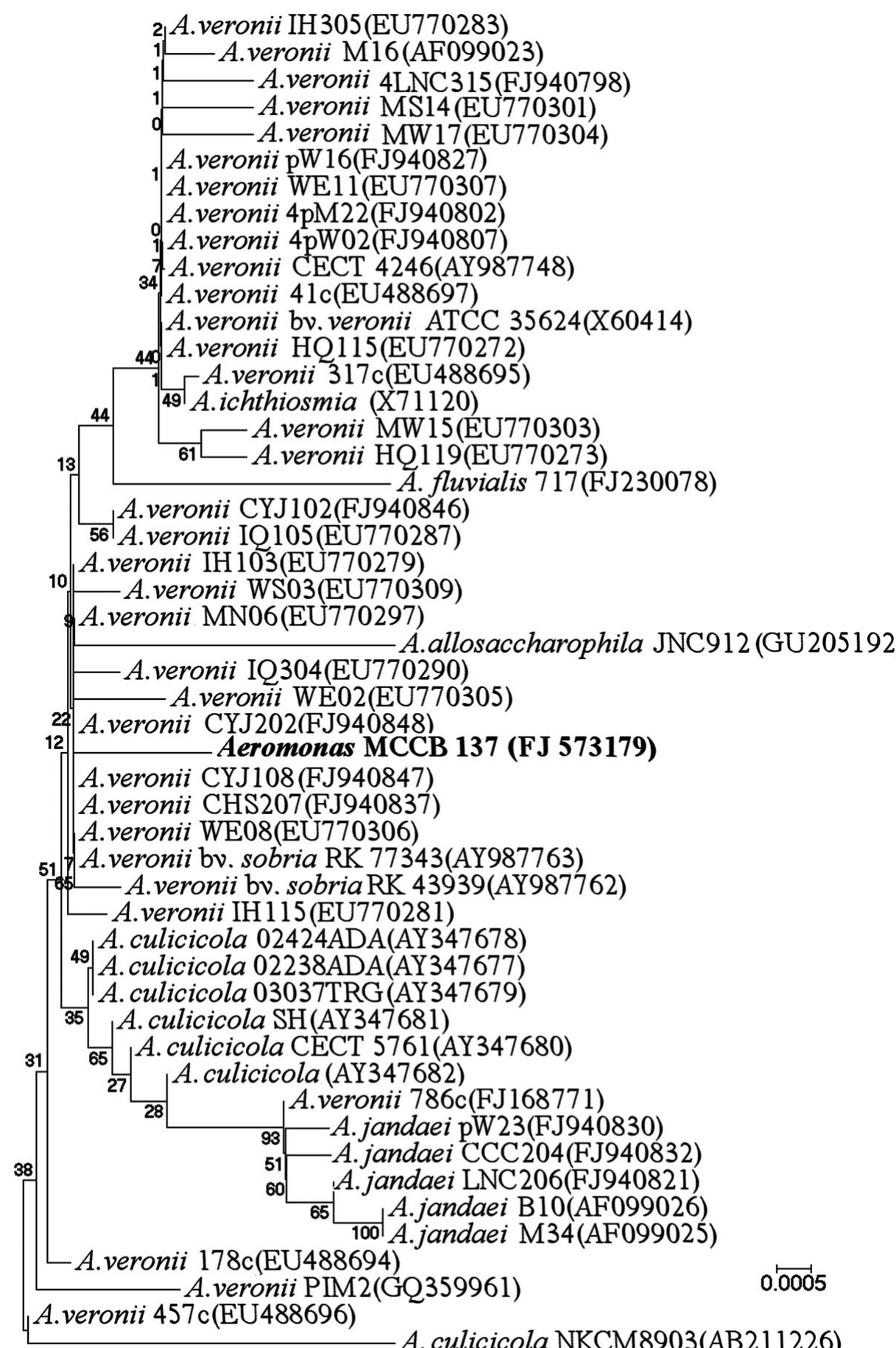

Fig. 1. Aeromonas spp. Neighbourjoining phylogenetic tree constructed with the 16S rRNA gene sequences of A. veronii MCCB 137 (in bold) with its most similar matches in GenBank using MEGA4. The percentages of replicate trees in which the associated taxa clustered together in the bootstrap test (1000 replicates) are shown next to the branches. The evolutionary distances were computed using the Kimura 2-parameter method and are shown as the number of base substitutions per site biovar sobria. Nevertheless, all isolates were negative for esculin hydrolysis and ornithine decarboxylase, which is characteristic of $A$. veronii biovar sobria. The phylogenetic tree that we constructed indicated the closeness of the isolate Aeromonas MCCB 137 with the Aeromonas spp. available in GenBank.

In our study, all isolates produced hydrolytic enzymes such as gelatinase, lecithinase, caseinase, chiti- nase, amylase, lipase and DNase, but not elastase. The cultures exhibited $\beta$-haemolysis, slime formation, hydrophobicity and cytotoxicity on the Hep-2 cell line. Extracellular proteases aid the organism in overcoming the initial host defence mechanism such as resistance to serum killing (Leung \& Stevenson 1988) and are needed for the maturation of exotoxins such as aerolysin (Howard \& Buckley 1985). Lipases play an 


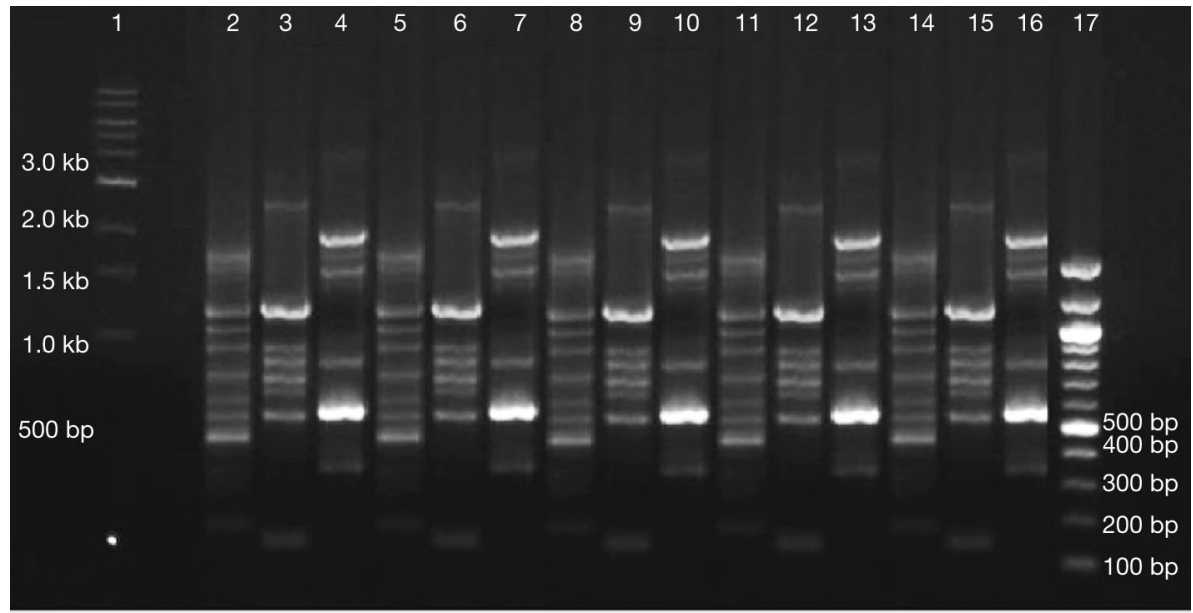

Fig. 2. Aeromonas veronii. RAPD profile of isolates from oscar (profiles of AOB-1, AOB-5, AOB-8, AOB-12 and AOB-15 are shown). The profiles were generated by using 3 primers (OPA-3, OPA-4 and OPD-20). Lane 1: 1 kb molecular mass marker; Lanes 2, 5, 8, 11 and 14: RAPD profile using OPD-20; Lanes 3, 6, 9,12 and 15: RAPD profile using OPA-3; Lanes 4, 7,10,13 and 16: RAPD profile using OPA-4; Lane 17: 100 bp molecular mass marker
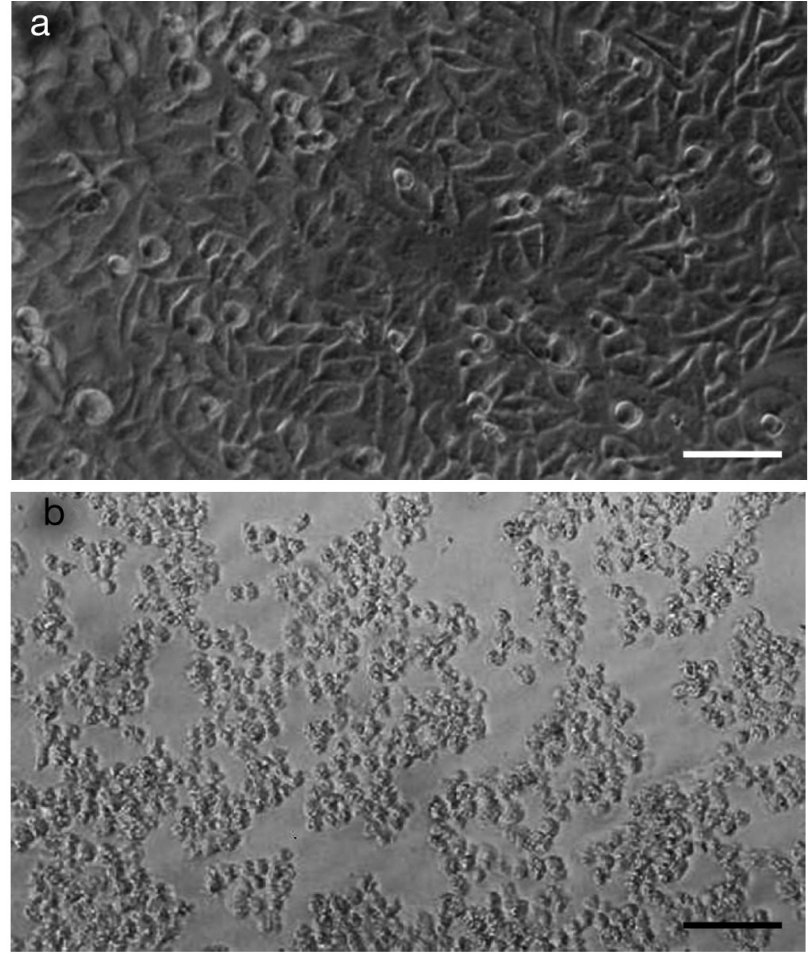

Fig. 3. (a) Normal Hep-2 cell line (Control). Scale bar = $250 \mu \mathrm{m}$. (b) Hep-2 cell line subsequent to the addition of the culture supernatant of Aeromonas MCCB 113 (125th dilution). Rounding and dislodgement of cells can be seen. Scale bar $=250 \mu \mathrm{m}$

important role in invasiveness and establishment of infections (Timpe et al. 2003). Members of the family Aeromonadaceae produce secreted phospholipases, some of which act as haemolysins and some as glyc-

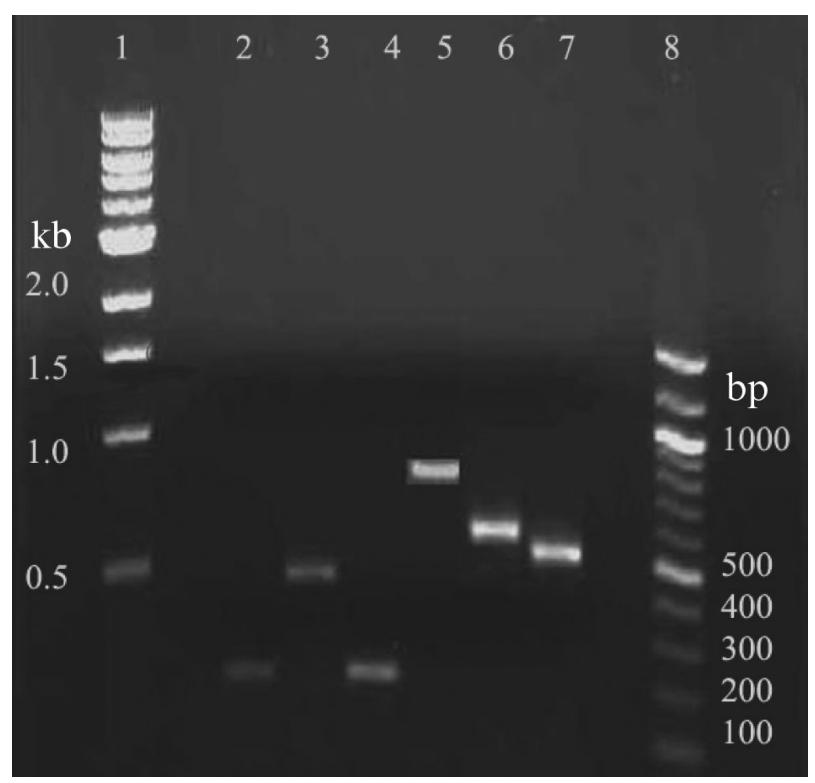

Fig. 4. Aeromonas veronii. PCR amplification of virulence genes from the genomic DNA of strain MCCB 137. Lane 1: $1 \mathrm{~kb}$ molecular mass marker; Lane 2: act (232 bp) gene; Lane 3: aerA gene (489 bp); Lane 4: gcat gene (237 bp); Lane 5: ascV gene (807 bp); Lane 6: ascF-ascG gene (789 bp); Lane 7: aexT gene (535 bp); Lane 8: 100 bp molecular mass marker

erophospholipid-cholesterol acyl-transferases (Scoaris et al. 2008).

The production of haemolytic toxins has been regarded as strong evidence for the pathogenic potential of aeromonads (Santos et al. 1999). All isolates were $\beta$-haemolytic to human red blood cells, strongly supporting virulence as suggested by Hazen et al. (1978). 
Table 3. Aeromonas veronii. Antibiotic susceptibility pattern of strains $(n=20)$ isolated from oscar. Disc content is in $\mu \mathrm{g}$ unless given as U. R: resistant; S: susceptible

\begin{tabular}{|c|c|c|c|}
\hline Antibiotic group & Antibiotic & isc content & Result \\
\hline \multirow[t]{23}{*}{ Beta lactams } & Amoxicillin & 10 & $\mathrm{R}$ \\
\hline & Ampicillin & 10 & $\mathrm{R}$ \\
\hline & Methicillin & 5 & $\mathrm{R}$ \\
\hline & Oxacillin & 1 & $\mathrm{R}$ \\
\hline & Piperacillin & 100 & $\mathrm{~S}$ \\
\hline & Penicillin G & $10 \mathrm{U}$ & $\mathrm{R}$ \\
\hline & Carbenicillin & 100 & $\mathrm{~S}$ \\
\hline & Cefaclor & 30 & $\mathrm{~S}$ \\
\hline & Cephadroxil & 30 & $\mathrm{~S}$ \\
\hline & Cephalothin & 30 & $\mathrm{~S}$ \\
\hline & Cefoperazone & 75 & $\mathrm{~S}$ \\
\hline & Cloxacillin & 1 & $\mathrm{R}$ \\
\hline & Cefazolin & 30 & $\mathrm{~S}$ \\
\hline & Cephalexin & 30 & $\mathrm{~S}$ \\
\hline & Cephradine & 25 & $\mathrm{~S}$ \\
\hline & Cephoxitin & 30 & $\mathrm{~S}$ \\
\hline & Ceftizoxime & 30 & $\mathrm{~S}$ \\
\hline & Ceftazidime & 30 & $\mathrm{~S}$ \\
\hline & Cephalodrine & 10 & $\mathrm{~S}$ \\
\hline & Cefamandole & 30 & $\mathrm{R}$ \\
\hline & Ceftriaxone & 10 & $\mathrm{~S}$ \\
\hline & Ticarcillin & 75 & $\mathrm{R}$ \\
\hline & Imipenam & 10 & $\mathrm{~S}$ \\
\hline Glycopeptides & Vancomycin & 5 & $\mathrm{R}$ \\
\hline \multirow[t]{3}{*}{ Polypeptides } & Bacitracin & $10 \mathrm{U}$ & $\mathrm{R}$ \\
\hline & Polymixin B & $50 \mathrm{U}$ & $\mathrm{R}$ \\
\hline & Colistin & 10 & $\mathrm{R}$ \\
\hline \multirow{7}{*}{ Aminoglycosides } & Amikacin & 10 & $\mathrm{~S}$ \\
\hline & Gentamycin & 10 & $\mathrm{~S}$ \\
\hline & Kanamycin & 30 & $\mathrm{~S}$ \\
\hline & Neomycin & 30 & $\mathrm{~S}$ \\
\hline & Netillin & 10 & $\mathrm{~S}$ \\
\hline & Streptomycin & 10 & $\mathrm{~S}$ \\
\hline & Tobramycin & 10 & $\mathrm{~S}$ \\
\hline \multirow{5}{*}{ Tetracyclines } & Doxyxycline $\mathrm{HCl}$ & 10 & $\mathrm{R}$ \\
\hline & Chlortetracycline & 30 & $\mathrm{~S}$ \\
\hline & Minocycline & 30 & $\mathrm{~S}$ \\
\hline & Oxytetracycline & 30 & $\mathrm{R}$ \\
\hline & Tetracycline & 10 & $\mathrm{R}$ \\
\hline Chloramphenicols & Chloramphenicol & 10 & $\mathrm{~S}$ \\
\hline Rifamycins & Rifampicin & 2 & $\mathrm{~S}$ \\
\hline \multirow[t]{2}{*}{ Lincosamides } & Clindamycin & 2 & $\mathrm{R}$ \\
\hline & Lincomycin & 2 & $\mathrm{R}$ \\
\hline Steroids & Fusidic acid & 10 & $\mathrm{R}$ \\
\hline \multirow[t]{3}{*}{ Nitrofurans } & Nitrofurazone & 100 & $\mathrm{~S}$ \\
\hline & Furazolidone & 50 & $\mathrm{~S}$ \\
\hline & Furaxone & 100 & $\mathrm{~S}$ \\
\hline \multirow[t]{4}{*}{ Sulphonamides } & Trimethoprim & 5 & $\mathrm{~S}$ \\
\hline & Sulphadiazine & 100 & $\mathrm{~S}$ \\
\hline & Sulphafurazole & 300 & $\mathrm{~S}$ \\
\hline & Sulphaphenazole & 200 & $\mathrm{~S}$ \\
\hline Quinolones/ & Ciprofloxacin & 5 & $\mathrm{~S}$ \\
\hline \multirow{9}{*}{ Fluoroquinolones } & Enrofloxacin & 5 & $\mathrm{~S}$ \\
\hline & Floxidine & 20 & $\mathrm{~S}$ \\
\hline & Pipemidic acid & 20 & $\mathrm{~S}$ \\
\hline & Nalidixic acid & 30 & $\mathrm{R}$ \\
\hline & Nitroxoline & 30 & $\mathrm{~S}$ \\
\hline & Norfloxacin & 10 & $\mathrm{~S}$ \\
\hline & Ofloxacin & 2 & $\mathrm{~S}$ \\
\hline & Pefloxacin & 5 & $\mathrm{~S}$ \\
\hline & Sparfloxacin & 5 & $\mathrm{~S}$ \\
\hline Aminocoumarins & Novobiocin & 30 & $\mathrm{~S}$ \\
\hline Nitrofurantoin & Nitrofurantoin & 100 & $\mathrm{~S}$ \\
\hline & Fosfomycin & 50 & $\mathrm{~S}$ \\
\hline \multirow{6}{*}{ Macrolides } & Azithromycin & 15 & $\mathrm{~S}$ \\
\hline & Clarithromycin & 15 & $\mathrm{~S}$ \\
\hline & Erythromycin & 10 & $\mathrm{R}$ \\
\hline & Tylosine & 15 & $\mathrm{~S}$ \\
\hline & Oleandomycin & 15 & $\mathrm{R}$ \\
\hline & Spiramycin & 30 & $\mathrm{~S}$ \\
\hline
\end{tabular}

High cell surface hydrophobicity is considered an advantage in the colonization of mucosal surfaces by bacteria and formation of biofilm and adhesion to epithelial cells (Scoaris et al. 2008). All isolates of Aeromonas studied here were strongly hydrophobic, with the percentage of adhesion being $56.9 \pm 0.311 \%$ (Lee \& Yii 1996). Slime production reflects a microorganism's capacity to adhere to specific host tissues and thereby to produce invasive micro colonies (Lilenbaum et al. 1998) and diverse illnesses (Tenover et al. 1988). All isolates of Aeromonas produced black colonies in Congo red agar with dry crystalline consistency and were regarded as slime positive.

The isolates were cytotoxic to the Hep-2 cell line. One of the most important virulence properties of haemolysins and enterotoxin of aeromonads involves exhibition of cytotoxicity in vitro (Ghatak et al. 2006). Microscopic examination of the cell line following exposure to and incubation with cell-free supernatant revealed cytopathic effects including rounding, shrinkage of cytoplasm and dislodgement of cells (Fig. 3).

In our study, all isolates showed uniformity in phenotypic characteristics, hydrolytic potential and RAPD pattern. Therefore, we selected 1 representative strain (Aeromonas veronii MCCB 137) for screening virulence genes and for the infection trial. Aeromonas MCCB 137 has the enterotoxin gene act, the haemolytic toxin genes aerA and gcat, and the type 3 secretion genes aex $T$, ascF-asc $G$ and $a s c V$, confirming its potential pathogenicity. All of these virulence genes encode for secreted enzymes and toxins that contribute to the pathogenicity of the organism. Earlier studies suggested that act possessed multiple biological activities, including haemolysis, cytotoxicity and lethality when injected into mice (Chopra et al. 2000, Sha et al. 2005). Aerolysin is an extracellular, soluble and hydrophilic protein exhibiting both haemolytic and cytolytic properties and is considered a putative virulence factor related to the pathogenicity of several Aeromonas strains (Biscardi et al. 2002, Epple et al. 2004). GCAT has lipase or phospholipase activity and could cause erythrocyte lysis by digesting their plasma membrane (Pemberton et al. 1997).

The genes encoding effector proteins, translocated by the TTSS, disrupt the cytoskeleton or interfere with cell signalling cascades of eukaryotic host cells (Galan \& Wolf-Watz 2006). aexT is a bifunctional protein with ADP-ribosylating activity and guanosine triphosphatase-activating protein (GAP) activity (Fehr et al. 2007). aexT mediates ADP-ribosylation of both muscular and non-muscular actin in vitro (Fehr et al. 2007), thereby preventing polymerization (Masignani et al. 2006). It also induces morphological changes in fish cells, including cell rounding and subsequent lysis 
(Fehr et al. 2007, Vilches et al. 2008). ascV is a gene that serves as an indicator for the presence of the TTSS machinery (Stuber et al. 2003), which encodes an inner membrane component of the TTSS apparatus, and ascF-ascG encode the needle complex and a chaperone, respectively (Ghosh 2004). Several previous studies have examined the prevalence of the TTSS among Aeromonas veronii isolates (Chacon et al. 2004, Burr et al. 2005). In our study, $a s c V$, ascF-asc $G$ and aex $T$ were detected, as was also reported by Silver \& Graf (2009).

The $\mathrm{LD}_{50}$ value of $10^{5.071} \mathrm{CFU} \mathrm{ml}^{-1}$ confirms the virulence of Aeromonas MCCB 137 according to Lallier \& Daigneault (1984). At the site of injection of the pathogen, ulceration commenced as sloughing off of the scales, followed by the occurrence of a haemorrhagic spot which progressed to form an epidermal lesion as observed earlier by Harikrishnan et al. (2003).

As Aeromonas spp. are zoonotic, it is imperative to combat the organism in the rearing facility, and for this purpose, we performed antimicrobial susceptibility tests on the organisms. As antibiotic susceptibility varies among Aeromonas species, it is better to identify the organism to species level prior to administration of the drugs (Trakhna et al. 2009). The multiple-antibiotic resistances of the isolates suggest the potential loss of fish including brood stock, as antibiotics might not protect a population from infectious death. The MAR index $>0.2$ suggests that the isolates originated from a high-risk source of antibiotic contamination. The widespread antibiotic use in the ornamental fish culture facilities might have resulted in the rapid spread of multidrug-resistant pathogens across the systems.

Here we characterized Aeromonas veronii associated with abdominal dropsy of oscar. The isolates possessed several virulence factors that could potentially play an important role in the development of dropsy in fishes. To our knowledge, this is the first report of virulent and multiple antibiotic resistant $A$. veronii associated with dropsy in oscar.

Acknowledgements. We thank the Marine Products Export Development Authority (MPEDA), Ministry of Commerce and Industry, Government of India (project code: 3/3/OFD/HO/ 2003 dated 25-02-2004), and the Department of Biotechnology (DBT), Government of India (project code: BT/PR4012/ AAQ/03/204/2003), for financial support. K.S. thanks MPEDA for a fellowship.

\section{LITERATURE CITED}

Altschul SF, Gish W, Miller W, Myers EW, Lipman DJ (1990) Basic local alignment search tool. J Mol Biol 215:403-410 > Altwegg M, Steigerwalt AG, Altwegg-Bissig R, Luthy-Hottenstein J, Brenner DJ (1990) Biochemical identification of Aeromonas genospecies isolated from humans. J Clin Microbiol 28:258-264

APHA (1995) Standard methods for the examination of water and wastewater, 19th edn. American Public Health Asso- ciation, American Water Works Association, and Water Pollution Control Federation, Washington, DC

Bauer AW, Kirby WMM, Sherris JC, Turck M (1966) Antibiotic susceptibility testing by a standardized single disc method. Am J Clin Pathol 45:493-496

Beeching SC (1995) Colour pattern and inhibition of aggression in the cichlid fish Astronotus ocellatus. J Fish Biol 47:50-58

Biscardi D, Castaldo A, Gualilo O, de Fusco R (2002) The occurrence of cytotoxic Aeromonas hydrophila strains in Italian mineral and thermal waters. Sci Total Environ 292: 255-263

- Burr SE, Frey J (2007) Analysis of type III effector genes in typical and atypical Aeromonas salmonicida. J Fish Dis 30: 711-714

Burr SE, Pugovkin D, Wahli T, Segner H, Frey J (2005) Attenuated virulence of an Aeromonas salmonicida subsp. salmonicida type III secretion mutant in a rainbow trout model. Microbiology 151:2111-2118

Carnahan AM, Altwegg M (1996) Taxonomy. In: Austin B, Altwegg M, Gosling PJ, Joseph S (eds) The genus Aeromonas. Wiley, New York, NY, p 1-38

Carnahan A, Hammontree L, Bourgeois L, Joseph SW (1990) Pyrazinamidase activity as a phenotypic marker for several Aeromonas spp. isolated from clinical specimens. J Clin Microbiol 28:391-392

Carnahan AM, Behram S, Joseph SW (1991) Aerokey II: a flexible key for identifying clinical Aeromonas species. J Clin Microbiol 29:2843-2849

Chacon MR, Soler L, Groisman EA, Guarro J, Figueras MJ (2004) Type III secretion system genes in clinical Aeromonas isolates. J Clin Microbiol 42:1285-1287

> Chopra AK, Xu XJ, Ribardo D, Gonzalez M, Kuhl K, Petersojn JW, Houston CW (2000) The cytotoxic enterotoxin of Aeromonas hydrophila induces proinflammatory cytokine production and activates arachidonic acid metabolism in macrophages. Infect Immun 68:2808-2818

Collee JG, Fraser AG, Marmion BP, Simmons A (1996) Practical medical microbiology. Churchill Livingstone, New York, NY

Epple HJ, Mankertz J, Ignatius R, Liesenfeld O, Fromm M, Zeitz S, Chakraborty T, Schulzke JD (2004) Aeromonas hydrophila beta-hemolysin induces active chloride secretion in colon epithelial cells (HT-29/B6). Infect Immun 72: 4848-4858

Ewing WH (1986) Edwards and Ewing's identification of Enterobacteriaceae, 4th edn. Elsevier Science Publishing, New York, NY

FAO (Food and Agricultural Organization of the United Nations) (2006) State of the world aquaculture. FAO Fish Tech Pap 500. FAO, Rome

Fehr D, Burr SE, Gilbert M, Alayer J, Frey J, Popoff MR (2007) Aeromonas exoenzyme $\mathrm{T}$ of Aeromonas salmonicida is a bifunctional protein that targets the host cytoskeleton. J Biol Chem 282:28843-28852

> Filler G, Ehrich JH, Strauch E, Beutin L (2000) Acute renal failure in an infant associated with cytotoxic Aeromonas sobria isolated from patient's stool and from aquarium water as suspected source of infection. J Clin Microbiol 38:469-470

Freeman DJ, Elakliner FR, Keane CT (1989) New method for detecting slime production by coagulase negative staphylococci. J Clin Pathol 42:872-874

> Galan JE, Wolf-Watz H (2006) Protein delivery into eukaryotic cells by type III secretion machines. Nature 444:567-573

Ghatak S, Agarwal RK, Bhilegaonkar KN (2006) Comparative study of cytotoxicity of Aeromonas spp. on four different cell lines. Comp Immunol Microbiol Infect Dis 29:233-241 
Ghosh P (2004) Process of protein transport by the type III secretion system. Microbiol Mol Biol Rev 68:771-795

Greenman SB, Rutten MJ, Fowler WM, Scheffler L and others (1997) Herbicide/pesticide effects on intestinal epithelial growth. Environ Res 75:85-93

Harikrishnan R, Nisha Rani M, Balasundaram C (2003) Hematological and biochemical parameters in common carp, Cyprinus carpio, following herbal treatment for Aeromonas hydrophila infection. Aquaculture 221:41-50

Hazen TC, Fliermans CB, Hirsch RP, Esch GW (1978) Prevalence and distribution of Aeromonas hydrophila in the United States. Appl Environ Microbiol 36:731-738

Henriques IS, Fonseca F, Alives A (2006) Occurrence and diversity of integrons and beta-lactamase genes among ampicillin resistant isolates from estuarine waters. Res Microbiol 157:938-947

Heuzenroeder MW, Wong CYF, Flower RLP (1999) Distribution of two hemolytic toxin genes in clinical and environmental isolates of Aeromonas spp. Correlation with virulence in a suckling mouse model. FEMS Microbiol Lett 174:131-136

> Hickman-Brenner FW, MacDonald KL, Seigerwalt AG, Fanning GR, Brenner DJ, Farmer JJ III (1987) Aeromonas veronii, a new ornithine decarboxylase positive species that may cause diarrhea. J Clin Microbiol 25:900-906

Hossain M (2008) Isolation of pathogenic bacteria from the skin ulcerous symptomatic gourami (Colisa lalia) through 16S rDNA analysis. Univ J Zool Rajshahi Univ 27:21-24

> Howard SP, Buckley JT (1985) Protein export by a gramnegative bacterium: production of aerolysin by Aeromonas hydrophila. J Bacteriol 161:1118-1124

> Janda JM, Kokka RP (1991) The pathogenicity of Aeromonas strains relative to genospecies and pheospecies identification. FEMS Microbiol Lett 90:29-34

Janda JM, Abbott SL, Khashe S, Kellogg GH, Shimada T (1996) Further studies on biochemical characteristics and serologic properties of the genus Aeromonas. J Clin Microbiol 34:1930-1933

> Jeffries CD, Holtman DE, Guse DG (1957) Rapid method for the determining the activity of microorganisms on nucleic acids. J Bacteriol 73:590-591

Jeney ZS, Jeney G (1995) Recent achievements in studies on diseases of the common carp (Cyprinus carpio L.). Aquaculture 129:397-420

Karunasagar I, Karunasagar I, Otta SK (2003) Disease problems affecting fish in tropical environments. J Appl Aquacult 13:231-249

> Kim JH, Hayward CJ, Joh SJ, Heo GJ (2002) Parasitic infections in live freshwater tropical fishes imported to Korea. Dis Aquat Org 52:169-173

Kimura M (1980) A simple method for estimating evolutionary rate of base substitutions through comparative studies of nucleotide sequences. J Mol Evol 16:111-120

Kingombe CIB, Huys G, Tonolla M, Albert MJ, Swings J, Peduzzi R (1999) PCR detection, characterization and distribution of virulence genes in Aeromonas spp. Appl Environ Microbiol 65:5293-5302

Kozinska A, Figueras MJ, Chacon MR, Soler L (2002) Phenotypic characteristics and pathogenicity of Aeromonas genomospecies isolated from common carp (Cyprinus carpio L.). J Appl Microbiol 93:1034-1041

Krumperman PH (1985) Multiple antibiotic indexing of E. coli to identify high-risk sources of fecal contamination of foods. Appl Environ Microbiol 46:165-170

Lallier R, Daigneault P (1984) Antigenic differentiation of pili from non-virulent fish pathogenic strains of Aeromonas hydrophila. J Fish Dis 7:509-572
Lee KK, Yii KC (1996) A comparison of three methods for assaying hydrophobicity of pathogenic vibrios. Lett Appl Microbiol 23:343-346

Lee YK, Kim HW, Liu CL, Lee HK (2003) A simple method for DNA extraction from marine bacteria that produce extracellular materials. J Microbiol Methods 52:245-250

> Lehane L, Rawlin GT (2000) Topically acquired bacterial zoonoses from fish: a review. Med J Aust 173:256-259

Leung KY, Stevenson RMW (1988) Characteristics and distribution of extracellular proteases from Aeromonas hydrophila. J Gen Microbiol 134:151-160

> Lilenbaum W, Nunes ELC, Azeredo MAI (1998) Prevalence and antimicrobial susceptibility of staphylococci isolated from the skin surface of clinically normal cats. Lett Appl Microbiol 27:224-228

> Lilley JH, Hart D, Richards RH, Roberts RJ, Cerenius L, Soderhall K (1997) Pan-Asian spread of single fungal clone results in large-scale fish kills. Vet Rec 140:653-654

Ma Z, Yang H, Li T, Luo L, Gao J (2009) Isolation and identification of pathogenic Aeromonas veronii isolated from infected Siberian sturgeon (Acipenser baerii). Wei Sheng Wu Xue Bao 49:1289-1294

- Martínez-Murcia AJ, Saavedra MJ, Mota VR, Maier T, Stackebrandt E, Cousin S (2008) Aeromonas aquariorum sp. nov., isolated from the aquaria of ornamental fish. Int J Syst Evol Microbiol 58:1169-1175

Masignani V, Pizza M, Rappuoli R (2006) Molecular, functional, and evolutionary aspects of ADP ribosylating toxins. In: Alouf JE, Popoff MR (eds) The comprehensive sourcebook of bacterial protein toxins. Academic Press Elsevier, Amsterdam, p 213-244

> McCormick JI, Hughes MS, McLoughlin MF (1995) Identification of Mycobacterium chelonae in a cichlid oscar, Astronotus ocellatus Cuvier, by direct cycle sequencing of polymerase chain reaction amplified 16s rRNA gene sequences. J Fish Dis 18:459-461

- Mosmann T (1983) Rapid colorimetric assay for cellular growth and survival, application to proliferation and cytotoxicity assays. J Immunol Methods 65:55-63

Nerland AH (1996) The nucleotide sequence of the gene encoding GCAT from Aeromonas salmonicida ssp. salmonicida. J Fish Dis 19:145-150

Ormen O, Ostensvik O (2001) The occurrence of aerolysinpositive Aeromonas spp. and their cytotoxicity in Norwegian water sources. J Appl Microbiol 90:797-802

Paiva PM, Nepomuceno FH (1989) On the reproduction in captivity of the oscar, Astronotus ocellatus (Cuvier), according to the mating methods (Pisces-Cichlidae). Amazoniana 10:361-377

> Pemberton JM, Kidd SP, Schmidt R (1997) Secreted enzymes of Aeromonas. FEMS Microbiol Lett 152:1-10

Plumb JA, Hanson LH (2010) Health maintenance and principal microbial diseases of cultured fishes, 3rd edn. John Wiley and Sons, Ames, IA

Rahman M, Navarro CP, Kuhn I, Huys G, Swings J, Mollby R (2002) Identification and characterization of pathogenic Aeromonas veronii biovar sobria associated with epizootic ulcerative syndrome in fish in Bangladesh. Pak J Biol Sci 68:650-655

Rahman MM, Somsiri T, Tajima K, Ezura Y (2004) Distribution of Aeromonas sp. emphasizing on a newly identified species of Aeromonas sp. T8 isolated from fish and aquatic animals in Southeast Asia. Pak J Biol Sci 7:258-268

> Reddy GSM, Aggarwal RK, Matsumotto GI, Sivaji SI (2000) Arthrobacter flavus sp. nov., a psychrophilic bacterium isolated from a pond in McMurdo Dry Valley, Antarctica. Int J Syst Evol Microbiol 50:1553-1561 
Reed MJ, Muench M (1938) A simple method for estimating fifty percent endpoints. Am J Hyg 27:493-497

Rosenberg K, Gutnick D, Rosenberg E (1980) Adherence of bacteria to hydrocarbons, a simple method for measuring cell-surface hydrophobicity. FEMS Microbiol Lett 9:29-33

Saitou N, Nei M (1987) The neighbor-joining method: a new method for reconstructing phylogenetic trees. Mol Biol Evol 4:406-425

Sambrook J, Russell DW (2001) Molecular cloning: a laboratory manual. Cold Spring Harbor Laboratory Press, Cold Spring Harbor, NY

Santos JA, Gonzalez CJ, Otero A, Garcia-Lopez ML (1999) Hemolytic and siderophore production in different Aeromonas species isolated from fish. Appl Environ Microbiol 65:5612-5614

Scoaris DDO, Colacite J, Nakamura CV, Nakamura TU, Filho BAA, Filho BPD (2008) Virulence and antibiotic susceptibility of Aeromonas spp. isolated from drinking water. Antonie Leeuwenhoek 93:111-122

Sha J, Pillai L, Fald AA, Galindo CL, Erova TE, Chopra AK (2005) The type III secretion system and cytotoxic enterotoxin alter the virulence of Aeromonas hydrophila. Infect Immun 73:6446-6457

Shao J, Liu J, Xiang L (2004) Aeromonas hydrophila induces apoptosis in Carassius auratus lymphocytes in vitro. Aquaculture 229:11-23

Shome R, Shome BR, Mazumder Y, Das A, Kumar A, Rahman H, Bujarbaruah KM (2005) Abdominal dropsy disease in major carps of Meghalaya: isolation and characterization of Aeromonas hydrophila. Curr Sci 88:1897-1900

Silver AC, Graf J (2009) Prevalence of genes encoding the type three secretion system and the effectors AexT and AexU in the Aeromonas veronii group. DNA Cell Biol 28:383-388

Soltani M, Mirzargar SS, Abrahimzadeh HA (1998) Occurrence of a motile Aeromonas septicemia in the imported ornamental fish, oscar, Astronotus ocellatus: isolation, characterization, and pathogenicity. J Fac Vet Med Univ Tehran 53:63-65

Sreedharan K (2008) Aeromonas associated with freshwater ornamental fish culture systems: characterization, pathogenicity and management. $\mathrm{PhD}$ thesis, Cochin University of Science and Technology

Staeck W, Linke H (1995) American cichlids. II. Large cichlids: a handbook for their identification, care, and breeding. Tetra Press, Melle

Stuber K, Frey J, Burnens AP, Kuhnert P (2003) Detection of type III secretion genes as a general indicator of bacterial virulence. Mol Cell Probes 17:25-32

Sudheesh PS, Jie K, Xu H (2002) Random amplified polymorphic DNA-PCR typing of Vibrio parahaemolyticus and $V$. alginolyticus isolated from cultured shrimps. Aquaculture 207:11-17

Editorial responsibility: Roland Anderson,

Seattle, Washington, USA
Swift S, Lynch JM, Fish L, Kirke DF, Tomas JM, Stewart GSAB, Williams P (1999) Quarum sensing-dependent regulation and blockade of exoprotease production in Aeromonas hydrophila. Infect Immun 67:5192-5199

Tamura K, Dudley J, Nei M, Kumar S (2007) MEGA4: Molecular Evolutionary Genetics Analysis (MEGA) software version 4.0. Mol Biol Evol 24:1596-1599

Tenover FC, Lancaster MV, Hill BC (1988) Characterization of staphylococci with reduced susceptibilities to vancomycin and other glycopeptides. J Clin Microbiol 36: 1020-1027

Thompson JD, Higgins DG, Gibson TJ (1994) CLUSTAL W: improving the sensitivity of progressive multiple sequence alignment through sequence weighting, position-specific gap penalties and weight matrix choice. Nucleic Acids Res 22:4673-4680

Timpe JM, Holm MM, Vanlenberg SL, Basrur V, Lafontaine ER (2003) Identification of a Moraxella catarrhalis outer membrane protein exhibiting both adhesion and lipolytic activities. Infect Immun 71:4341-4350

Toksen E (2006) Argulus foliacesus (Crustacea: Branchiura) infestation on oscar, Astronotus ocellatus (Cuvier, 1829) and its treatment. EU J Fish Aquat Sci 23:177-179

Trakhna F, Harf-Monteil C, Abdelnour A, Maaroufi A, Gadonna-Widehem P (2009) Rapid Aeromonas hydrophila identification by TaqMan PCR assay: comparison with a phenotypic method. Lett Appl Microbiol 49:186-190

Tukmechi A, Hobbenaghi R, Holasoo RH, Morvaridi A (2009) Streptococcosis in a pet fish, Astronotus ocellatus: a case study. World Acad Sci Eng Tech 49:14-15

- van der Marel M, Schroers V, Neuhaus H, Steinhagen D (2008) Chemotaxis towards, adhesion to, and growth in carp gut mucus of two Aeromonas hydrophila strains with different pathogenicity for common carp, Cyprinus carpio L. J Fish Dis 31:321-330

Vilches S, Wilhelms M, Yu HB, Leung KY, Thomas JM (2008) Aeromonas hydrophila AH-3 AexT is an ADP-ribosylating toxin secreted through the type III secretion system. Microb Pathog 44:1-12

Von B (2010) Fundamental information regarding oscar fish. http://ezinearticles.com/?Fundamental-InformationRegarding-Oscar-Fish\&id=4572555

Wahli T, Burr SE, Pugovkin D, Mueller O, Frey J (2005) Aeromonas sobria, a causative agent of disease in farmed perch, Perca fluviatilis L. J Fish Dis 28:141-150

Wilcox MH, Cook AM, Eley A, Spencer RC (1992) Aeromonas spp. as a potential cause of diarrhoea in children. J Clin Pathol 45:959-963

Wu CJ, Wu JJ, Yan JJ, Lee HC and others (2007) Clinical significance and distribution of putative virulence markers of 116 consecutive clinical Aeromonas isolates in southern Taiwan. J Infect 54:151-158

Submitted: August 2, 2010; Accepted: October 18, 2010 Proofs received from author(s): February 15, 2011 